EXEMPLARIa Classica

Journal of Classical Philology

20, 2016, pp. 91-101

ISSN 1699-3225

\title{
A NEW READING OF CATULLUS 25.5
}

\author{
R. K. R. THORNTON \\ rkrthornton@btinternet.com
}

A. ElLiot

alistair.elliot@btinternet.com

SUMMARY

The fifth line of Catullus's poem 25 is a notorious crux. 74 emendations have been proposed since the fifteenth century. Thornton and Elliot propose a new line to satisfy the demands of metre, sentencestructure, and coherence with the corpus; and give a closely argued case for how the amendment proposed derives from the scribe's marks.

KEY WORDS

Catullus; emendation; poem 25.5.

\section{RESUMEN}

El verso quinto del poema 25 de Catulo es un pasaje difícil de interpretar. Se han propuesto hasta 74 conjeturas desde el siglo XV. Thornton y Elliot proponen un nuevo lectura para satisfacer las necesidades de la métrica, la estructura de la frase y la coherencia del texto dentro del corpus, y argumentan de qué forma surgió la conjetura propuesta a partir de las anotaciones del copista.

Palabras Clave

Catulo; conjetura; poema 25.5.

Fecha de recepción: 30/11/2015

Fecha de aceptación y versión final: 17/12/2015

Carmen 25 of Catullus's collection is a typical blustering performance, castigating the effeminate Thallus for stealing various items from a party where the guests were yawning, and threatening him with dire retribution. Here is the text as printed by R. A. B. Mynors in his authoritative 1958 Oxford Classical Text, with his cruces desperationis in line 5 . 
Cinaede Thalle, mollior cuniculi capillo vel anseris medullula vel imula oricilla vel pene languido senis situque araneoso, idemque, Thalle, turbida rapacior procella, cum diva $†$ mulier aries $\dagger$ ostendit oscitantes, remitte pallium mihi meum, quod involasti, sudariumque Saetabum catagraphosque Thynos, inepte, quae palam soles habere tamquam avita. quae nunc tuis ab unguibus reglutina et remitte, ne laneum latusculum manusque mollicellas inusta turpiter tibi flagella conscribillent, et insolenter aestues, velut minuta magno deprensa navis in mari, vesaniente vento.

There is an excellent translation by J. Michie, perhaps the most satisfactory of Catullus's many translators, who translates the fourth and fifth lines as follows:

And yet by moonlight you're a hard man, Thallus;

When the attendants doze, you have the habit

Of pouncing quicker than a hurricane ${ }^{1}$.

Although Michie used Mynors' text for the most part, he did occasionally depart from it, and line 5 of this poem is one of those occasions. The version he translated ran: cum luna vestiarios ostendit oscitantes ('when the moon reveals the cloakroom attendants are dozing'). Although poem 25 has other textual problems, there is none greater than that of line five. Scholars and editors have worried at it literally for centuries. CatullusOnline.org, the website run by D. Kiss ${ }^{2}$, offers the texts of all Catullus's poems, a listing of all conjectural corrections, and, most usefully, illustrations of the manuscripts. The website lists over 70 suggested emendations, ranging from the end of the fifteenth century until the twenty-first, and all indicate the intractability of the line.

D. F. S. Thomson's edition ${ }^{3}$ prints cum laeva nummularios offendit oscitantes ('when the left hand strikes the yawning bankers or moneychangers'), the edition of A. Pérez Vega and A. Ramírez de Verger ${ }^{4}$ printed O. Skutsch's reconstruction cum dives arca rimulas ostendit oscitantes,

${ }^{1}$ J. Michie, The Poems of Catullus, London 1969.

2 We are also grateful to him for comments on our suggestions. We would also like to acknowledge suggestions and comments from Professor B. Gibson and an unnamed reader, who were very helpful and instructive; and from Professor A. Woodman.

${ }^{3}$ Toronto 2003.

${ }^{4}$ Sevilla-Huelva 2005. 
and G. P. Goold in his Catullus ${ }^{5}$ also uses the Skutsch emendation, which is rendered as 'when a well-stocked linen-chest has openings showing'. Having offered the line suggested by Haupt - Cum diua mulierarios ostendit oscitantes ('when the goddess shows these men in the power of women are yawning' or 'womanish men are yawning') - H. Bardon commented in his Catulli Carmina 6 , "Mais cela reste très problématique". Without being an expert on Roman dinners, one suspects that money-changers, linen-chests with holes in and gyneolaters are out of context here.

The variety of editions and suggestions seems almost endless; G. Lee in his The Poems of Catullus ${ }^{7}$ prints cum Diua miluorum aues ostendit oscitantes, which he translates as 'Whenever the Goddess of hawks gives notice birds are napping'; P. Whigham's bilingual edition ${ }^{8}$ prints Mynors' line, and largely ignores it in his translation except for 'its crop of gaping sailors'; K. Quinn, in the revised edition of his Catullus. The Poems ${ }^{9}$ prints cum diua Murcia arbitros ostendit oscitantes, which he renders as 'When the goddess of sloth shows him that onlookers are nodding; C. and L. Zukofsky, in their Catullus ${ }^{10}$ print Mynors' line without its cruces desperationis but are interested only in sound and render the line rather desperately as 'come diva mull over Aries - oscine oscitancy', which is even more obscure than its original.

Two $21^{\text {st }}$-century approaches to the line will suffice to demonstrate its continued resistance to correction. P. Green's The Poems of Catullus reads the line as cum diua Murcia ebrios ostendit oscitantes and translates it as 'whenever heavenly sloth reveals the tipsy diners nodding'11. Finally J. M. Trappes-Lomax, in his witty and thorough Catullus A Textual Reappraisal notes that "1. 5 has given endless trouble and no satisfying emendation of V's mulier aries/alios/ aues has so far been reached" and offers quom <lychnus ostiarios> ostendit oscitantes ('when the lamp reveals the porters yawning'), commenting that "it seems in any case no worse than the suggestions already made" 12 .

It seems impertinent to offer yet another reading, after Scaliger and many scholars have tried their hand at making sense of it; but we are rash enough to think that we have an idea of what Catullus wrote (as, we suppose, did all those who previously attempted to unravel and re-knit the line). More particularly we also think we can see how some early transcriber of the line created the words which have been handed down.

\footnotetext{
${ }^{5}$ London 1983.

${ }^{6} \mathrm{H}$. Bardon, Catulli Carmina, Brussels 1978.

${ }^{7}$ Oxford 1991.

${ }^{8}$ Berkeley 1969.

${ }^{9}$ London 1973

${ }^{10}$ London 1963.

${ }^{11}$ London 2005, 70-1.

${ }^{12}$ Swansea 2007, 81.
} 
We ought first to give a brief account of the transmission of the manuscript to indicate how we arrive at the position we are in. All texts of Catullus's poems derive ultimately from a manuscript of Catullus's poems which surfaced for a while in Verona, Catullus's birthplace, in about 1290. It is usually designated $[V]$, the square brackets indicating that it is not extant. Of this a copy, designated $[A]$, was made. This copy itself was also lost, but not before two copies had been made of it. The first copy, $O$, the manuscript now in the Bodleian Library in Oxford, was made in about 1370. The second copy, made at about the same time, $[X]$, once belonged to Petrarch, but it too has been lost, although two copies had been made of it which survive, the first called $G$, now in the Bibliothèque nationale de France in Paris, and the second $R$, now in the Biblioteca Apostolica in the Vatican. Those curious to see high quality images of $O$ and $G$ can find them on the CatullusOnline website.

Since none of the extant manuscripts $O, G$, or $R$, makes particular sense of the line, the errors must go back at least to the parent manuscript $[A]$. And since a lost exemplar $[X]$ stands between both $G$ and $R$ and the lost archetype $[A]$, we will concentrate on $O$ as being nearer to the source. Because of the nature of the errors that we think took place, much of the corruption of this line would have taken place during the period when it was transcribed in the Italian Gothic minuscule hand in which the extant manuscripts are written.

The spur to looking at this line was simply that I was attempting a translation of poem 25, where I found a selection of readings of line 5. Most of the proposed emendations offered little that was convincing. I felt that I needed to understand what the line might have been, and rather naïvely set about postulating alternatives. Luckily Alistair Elliot, who is an experienced classicist and translator, was at hand to collaborate by knocking my sillier suggestions on the head, ensuring that the rules of scansion and elision were correctly observed, making counter-suggestions, and satisfying himself that what was finally proposed was a credible Latin line.

Any line which we proposed had to satisfy four demands: 1) to make sense of the poem as a whole and ensure that it tied in with other poems by Catullus; 2) to fit the iambic tetrameter catalectic form; 3) to make grammatical sense; and 4) to explain as fully and as precisely as possible the process by which the misreadings might have occurred.

To deal with the poem, we need to begin with a poem earlier in the sequence, number 12 . This is another invective against a thief:

Marrucine Asini, manu sinistra non belle uteris: in ioco atque uino tollis lintea neglegentiorum. hoc salsum esse putas? fugit te, inepte: quamvis sordida res et inuenusta est. 
non credis mihi? crede Pollioni

fratri, qui tua furta uel talento

mutari uelit; est enim leporum

differtus puer ac facetiarum.

quare aut hendecasyllabos trecentos

10

exspecta, aut mihi linteum remitte,

quod me non mouet aestimatione,

uerum est mnemosynum mei sodalis.

nam sudaria Saetaba ex Hiberis

miserunt mihi muneri Fabullus

et Veranius; haec amem necesse est

ut Veraniolum meum et Fabullum.

This is my translation:

Asinius Marrucinus, during the fun and wine

Your left hand's ill-employed in things of mine:

When no-one's looking, up you come and steal

Napkins. You think that's neat? Wrong, imbecile.

It's an utterly foul and tasteless thing to do.

You don't believe me? Ask Pollio, your brother, who

Would pay off all your pilferings and be glad

To - though it cost a fortune; he's a lad

Well versed in pleasantries and works of wit.

Therefore, either expect satiric shit

In bucketloads, or get my napkins returned.

It's not the money as far as I'm concerned;

They remind me of my friends, I should explain -

Saetaban napkins Fabullus and Veran-

-ius sent over to me as a gift from Spain;

And my love for what they gave me is as full as

My affection for Veranius and Fabullus.

As H. Dettmer says in her Love by the Numbers (New York, 1997), "In theme and in many of its details, c. 25 recalls c. 12 " and she goes on to list the similarities: the setting at a banquet, the theft of the Spanish napkins, the taking advantage of the slightly tipsy guests, the denouncing of the thief as inepte, and the threat of punishment by writing. One may not wish to go as far as identifying Thallus with Asinius Marrucinus ${ }^{13}$, but there are noticeable links between the poems. At the very least, poem 12 provides a

${ }^{13}$ E. T. Merrill in his Catullus, Harvard 1893, wrote: "Thalle: nothing further is known of him, though unsatisfactory attempts have been made to identify him with Asinius Marrucinus of Catul 12.1 by reason of the similar charge against him". 
possible pattern ${ }^{14}$, and we feel that the subject and the event are, if not the same, at least sufficiently similar to warrant comparison. For us significantly, it is the left hand which is employed in poem 12; and Catullus does make the threat that Asinius Marrucinus can expect three hundred hendecasyllables if he doesn't hand back the goods. Poem 25 might not be hendecasyllables or of that length, but it could be a Catullan token of intent in that direction. It is true that the tone of 12 is lighter and that of 25 is cruder, but if the theft had been repeated, Catullus could have taken the gloves off.

Let us look at the manuscript $O$ at this passage (Catull. 25.5):

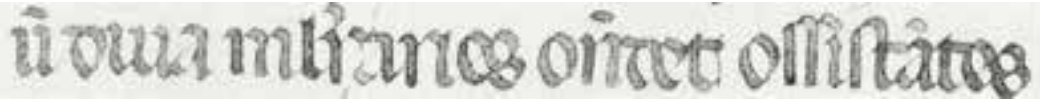

Line 25.5 in the fourteenth-century manuscripts is not quite as we find it in editions today, and we need to go back as far as we can to be able to see all the clues to what it might have read before corruption. In $O$ the line reads $C \tilde{u}$ diua mlraries oñdet ossistãtes (allowing for typographic approximations to the abbreviations of the $\mathrm{ms}$ ). This is not quite the line given in many texts as cum diua mulier aries ostendit oscitantes, a line made up of Latin words but not adding up to much sense.

The most fixed elements of the various alternative readings are the beginning and the end: cum and oscitantes, which we happily accept. The grammar of the previous line suggests that cum might well be expected; while oscitantes, meaning 'yawning' or 'drowsy', fits the sense of the stealing being done while people are inattentive (in ioco atque vino - 'in a merry drunken mood' - as line 2 of poem 12 says). E. T. Merrill ${ }^{15}$ reasonably says that it must mean 'off their guard', which suits the parallel with the earlier poem.

The second word from the end of the line is generally given as ostendit, a good Latin word, which might suggest 'displaying', 'exhibiting' or 'showing'. We came to feel however that such a reading was a distraction, since we considered that Thallus was behaving rather like Asinius Marrucinus. If the line were to echo the use of the left hand from poem 12, ostendit would not be appropriate, whereas tendit would be familiar Latin for reaching out a hand, though it is usually transitive and would require an object. The os which has traditionally formed the beginning of ostendit might not be part of that word at all, but instead be the ending of a previous word agreeing

${ }^{14}$ In her recent book, Translation as Muse, Chicago 2015, E. M. Young develops the idea that "In both structure and story line, poem 25 replicates the basic contours of the earlier napkin poem" (65).

${ }^{15}$ E. T. Merrill, Catullus, Cambridge 1893. 
with 'oscitantes' (the word-division of the manuscript is not always precise). The problem was to find what words fitted this scenario, and the metre, and the grammar, and the orthography.

In poem 12, Asinius Marrucinus had made ill use of his left hand, sinistra, a word which Catullus uses five times elsewhere in the collection (12.1,29.15, $45.8,45.17$, and 47.1), but we could not at first find a place for it in the lines we tried. We had the same problem with laeva, another attractive possibility and one used in other proposed amendments, since it means 'left hand' and looks superficially rather like diva in the line commonly printed. We also looked at who might be yawning at the banquet and experimented with a variety of guests: auditores, and hospites, though the metre usually placed those in a position which left us to find a single syllable before oscitantes, and none of our suggestions (such as nos) read well.

We examined the line in the hand of the $O$ manuscript, and thought that the end of the line to be copied must look very close to: er aries ostendit oscitantes. Adjusting slightly the word divisions, and conscious that some letter forms might be mistranscribed, we proposed that this might have looked like erariesos tendit oscitantes, which, reading eb for era, suggested ebriosos tendit oscitantes. Versions using ebrios have been tried before. The lists in the CatullusOnline website give us cum cena maior ebrios ostendit oscitantes $^{16}$, conuiua cum ebriosior se tendit oscitanter ${ }^{17}$, and cum diua Murcia ebrios ostendit oscitantes ${ }^{18}$. We were happy to light upon the simple word ebriosos, which fits the metrical needs and the grammar and goes along with the description 'yawning'. The word is also used only two poems later in 27.4 to describe the mistress of the feast Postumia in the line ebrioso acino ebriosioris. In that poem it describes not a disgusting state of drunkenness but a fully merry state, as at a feast. We concluded that the word ebriosos fitted all the demands well. The description 'yawning' at the end of the line could be applied to the replete guests who had imbibed a little too much of the wine to be careful about their property.

We now had a line which had begun to reflect closely the situation of poem 12, and sinistra looked a possible candidate for something to be stretched towards the drunken guests to take napkins. The word has a distinctive metrical shape and, if the end of the line was as we had begun to think (ebriosos tendit oscitantes), it would only fit in the second foot. That would leave two single-syllable gaps in the first half of the line: Cum ... sinistra ... ebriosos tendit oscitantes. The question arises therefore as to what was being stretched out; and by whom; and what is governing the accusatives of the yawning drunks. The manuscript versions are not a great deal of help here, so we postulated a subject for tendit and a preposition

${ }^{16}$ F. Hermes, Beiträge zur Kritik und Erklärung des Catull, Frankfurt a. O. 1888, 10.

${ }^{17}$ Th. D. Papanghelis, "Crux Catulliana (A Note on 25.5)", Latomus 39, 1980, 409-11.

${ }^{18}$ P. Green, The Poems of Catullus. A Bilingual Edition, Berkeley 2005. 
for the drunks. We considered that $t u$ was the most likely subject, since the whole poem is addressed to Thallus ${ }^{19}$. This would require changing tendit to tendis, which has not been previously suggested, though the gothic ' $\mathrm{t}$ ' and long 's' are not very far apart, and sinistra to sinistram. The simple preposition in could govern the accusative drunks and indicate the aggressive reaching towards them. Our proposed line would thus read:

cum tu sinistram in ebriosos tendis oscitantes

When you stretch your left hand towards the tipsy yawning (guests)

It is perhaps worth commenting at this stage that, although one loses the attractive initial alliteration of ostendit oscitantes, one does gain a rather more pervasive and subtle sound pattern in the groups made up of vowel $+s$ : cum tu sinistram in ebriosos tendis oscitantes.

We felt support might lie in the orthography, and it is worth reminding the reader of the often-quoted complaint of the scribe, probably copied from an earlier scribe, in manuscript $G$ in 1375 , where he sets out just how difficult to read was the manuscript he was copying:

Tu lector quicumque ad cuius manus hic libellus obvenerit scriptori da veniam si tibi coruptus videbitur. Quoniam a corruptissimo exemplari transcripsit. non enim quodpiam aliud extabat, unde posset libelli huius habere copiam exemplandi. Et ut ex ipso salebroso aliquid tamen suggeret decrevit pocius tamen coruptum habere quam omnino carere. Sperans adhuc ab alliquo alio fortuite emergente hunc posse corigere. Valebis si ei imprecatus non fueris ${ }^{20}$.

You, reader, whoever you are into whose hands this little book may find its way, grant pardon to the scribe if it appears to you corrupt. For he transcribed it from an extremely corrupt exemplar. For there was nothing else available, from which he could have the opportunity of copying this book; and in order to put together something from this rough source, he decided that it was better to have it in a corrupt state than not to have it at all, while hoping still to be able to correct it from another copy, if by chance one should happen to emerge. Fare you well, if you do not curse him.

We looked carefully at the orthography to see if the text which the scribe wrote down could have a legitimate relationship with the line we suggest

19 There are at least seventeen occasions in the corpus where 'tu' is the second syllable in a line, and four of them bear comparison: 8.7, 30.5, 30.11, and 76.11.

${ }^{20}$ MS $G$ (the Bibliothèque nationale de France, Parisinus lat. 14137), fol. 36r. One can read the manuscript on the CatullusOnline website. 
he was trying to copy. The mistakes may of course have been made by any previous transcriber using the Italian Gothic minuscule. The invaluable CatullusOnline website gives us useful reproductions of manuscripts $O$ and $G$, so that we can examine the characteristics of this hand. We should remember here that manuscript abbreviations might have added to the difficulty. J. M. Trappes-Lomax points out "the rule that any set of minims (e.g. $n i$ and $m$ ) is likely to be confused with any vaguely similar set of minims. Likewise the scribes habitually failed to distinguish between $t$ and $c, f$ and long $s, a$ and $e$, $e$ and $o$... Similarly the virgula over a vowel indicating a following $n$ or $m$ is so easily lost that, for example, $O$ 's ocio at 44.15 is just as likely to stand for ocima as for otio" (op. cit., 19).

In examining the manuscript, it is useful to follow our earlier procedure by beginning at the ends. Cum is seldom disputed at the beginning; while ries ostendit oscitantes (apart from the $s$ for $t$ ) differs little in letter forms and only minimally in word spacing from our proposed riosos tendis oscitantes. We assumed those parts of the line as not needing extended argument. This left us to decide whether the manuscript's diua mulier a could be a mistaken reading of our tu sinistram in eb, which looks on the face of it something of a difficulty.

The $t u$ for $d i$, however, is not a serious problem, although this has never been suggested before. We need go no further than the third line of the first poem of the manuscript ( $t u$ solebas in 1.3) to see that the cross of the $t$ in that word leads the scribe into the downstroke of the first minim of the $u$, thus making it look like a letter $d$, so we can see how it could easily be read as $d i$, the first syllable of diua and matching its three pen strokes. In our fanciful reconstruction of the moment when the scribe made his misreading we think that his initial mistake of $d i$ for $t u$ could have led to reading diua as a word which completed the letters he had transcribed, and so led on to his subsequent misreadings.

Could the remaining letters ua mulier a possiby derive from sinistram in $e b$ ? We must remember that the shape of medial $s$ in this hand is a long $f$, so that the downstroke can be more easily mistaken for a minim of another letter if the loop is not clearly written or there is some other reason for the text to be obscure. There are six downstrokes of the quill needed to write finif (there is no abbreviation of this part of the word in the other occurrences in the manuscript); there are six downstrokes required to write the letters $u a$ $m$ with a small loop for the bowl of the $a$. So $u a m$ could be an attempt to represent a misread finif. If that were so, it only remains to find whether uliera could derive from our proposed tram in ebr.

At this point, reference back to $O$ is useful. One sees there that the letters written are not ua mulier a but ua mlra with a virgula over the $r$. This means that we have to decide whether lra could derive from tramineb. The abbreviation in the $O$ ms reminds us that there may well have been 
abbreviation in the text which the scribe was trying to read and copy. The ending of sinistra in other parts of the manuscript (12.1, 29.15, 45.8, and 45.17 ) is rendered by a letter $t$ followed by a symbol (a comma plus a line) which represents $r$ followed by a vowel. We could therefore be looking at a hypothetical original reading [t'zeb], much nearer than one would have supposed to lra. The copyist's $l$ could be a misreading of the $t$; the abbreviation would represent the manuscript's abbreviation for $r+v o w e l$ and a hurried and squashed $\bar{i} e b$ could have been misread as $a$, the medial stroke of the $e$ being misread for the bowl of the $a$ and the right side of the loop of the letter $b$ being merged in the following letter. It is not infrequent for the right hand side of a letter $b$ to be obscured in this way (see for example the $b$ in libellum in the very first line of $O$ or the merging of the d with its following letter in the line reproduced above).

Here is a diagram of the correspondences:

\begin{tabular}{|l|l|l|l|l|l|l|l|}
\hline$M S O$ & $\mathrm{Cu}$ & $\mathrm{di}$ & ua $\mathrm{m}$ & l'́ra & aues os & oñdet & offiftãtes \\
\hline printed line & cum & $\mathrm{di}$ & ua $\mathrm{mu}$ & liera & ries os & tendit & oscitantes \\
\hline proposed line & cum & tu & finif & t'īeb & riofos & tendis & ofcitantes \\
\hline
\end{tabular}

More convincing is to see what the handwriting might have looked like, and, remember, the scribe found it difficult to read. So, we give below a rough attempt to represent what we imagine the original and the copy might have looked like, to suggest how easily the mistakes could have been made if there were some damage to the original.

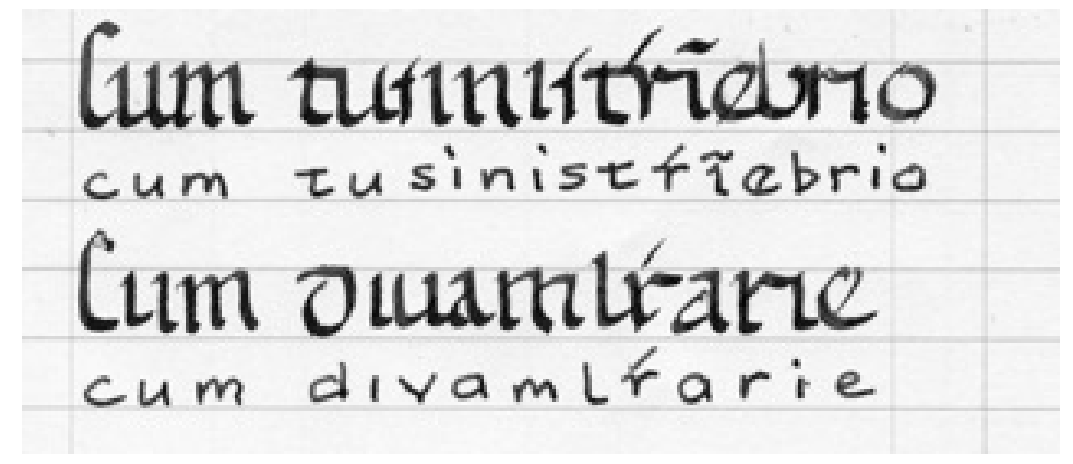

We cannot know whether there was damage to the text that made it difficult to read (staining or cropping or fading) or if it was so 'roughly written' (to quote the scribe) that things like the abbreviations were misread or not noticed by the copyist; and we cannot have a clear idea of the intelligence or otherwise of the scribe; but the shapes of the words seem to allow our reading and reinforce its other virtues. 
The closeness of the line which the scribe actually wrote to the line which we postulate that he (or a previous scribe) was trying to copy suggests that orthography, the demands of grammar, the verse form, the relationship to other Catullan work, and the general sense combine to make this a highly plausible new Catullan line. It may not be intrinsically a very exciting line, but the excitement comes from finding a convincing solution to a sixhundred year old problem. line 5:

So I could now translate Catullus 25 , incorporating the new reading of

You old queen, Thallus, softer than a rabbit's fur,

Or the inside of an ear, or down from a goose's breast,

Or an old man's cock, in cobwebs laid to rest;

You, Thallus, whose left hand whirlwind's a-stir,

Rampaging through the tipsy, yawning guests;

Send back to me the cloak you snatched from my rooms,

My Spanish napkin, and my Bithynian views;

Idiot, flaunting them like some family heirlooms.

Now, give them back; unglue your sticky claws,

Or those soft little hands, and your downy behind

Will be scrawled on with an unremitting whip,

And you'll find new ways to squirm, like a tiny ship

Caught in enormous seas, in a furious wind. 
